\title{
WOODEN TEXTILE TOOLS FROM MEDIEVAL POLAND
}

\begin{abstract}
Wooden textile tools are very rare archaeological finds. The reasons for this are various and one of them is, e.g., unstable environment, which results in decomposition of objects made of organic materials. Another reason is the lack of sufficient knowledge of textile tools by researchers responsible for archaeological research, who interpret such finds falsely. Yet another and rather frequent reason is a deficiency of publications on this issue. Therefore, very few weaving tools appear in archaeological literature. An assemblage of such objects comes from the exploration in the Opole settlement and an island in Żółte, Site 33 on Lake Zarańskie, West Pomerania (it has been the most numerous collection of weaving tools in Poland so far). Studies of archaeological layers in Gdańsk delivered only a few objects, which are a perfect complement of our knowledge of weaving production of the Middle Ages and the modern period. We should also remark that the artefacts from Żółte, apart from those from Gdańsk and Opole, are the best examples of using wooden textile tools by small communities. It leads to a conclusion that these groups were self-sufficient in textile manufacturing, starting with preliminary yarn processing and finishing with producing woollen and linen textiles.
\end{abstract}

Keywords: textile tools, spindles, distaffs, weaving sword, netting needle, wooden pulley, Poland

In most cases archaeological evidence documents clay spindle whorls and loom weights, which indicate that textile manufacturing developed practically in all parts of the world, not only in Europe. All other tools were usually made of wood that decomposed with time, and even if they are excavated, they are not correctly interpreted by archaeologists. Therefore, every piece of information concerning weaving instruments made of organic materials is precious.

It happens occasionally, however, that during archaeological explorations conducted in urban over-ground excavations or in the course of exploration of Polish lakes, researchers are able to identify some textile tools. One of them is a weaver's comb identified in early medieval layers in Lake Lednica. The tool was made of a tree branch, whose natural long sprouts served as teeth. Their length (about $5 \mathrm{~cm}$ ) and a double teeth row in some of its parts was absolutely sufficient for combing wool. ${ }^{1}$ Hoffmann claims that such combs were multifunctional tools and they could also

* Institute of Archaeology, Nicolaus Copernicus University in Toruń; (D) https://orcid.org/0000-0001-5128-9754; m.grupa@wp.pl

${ }^{1}$ Grupa 2000, 141. In this case we can presume that the object is a very primitive version of a comb; by using it in fleece processing, no high quality wool could be obtained. serve as a special flax-combs ${ }^{2}$ and as instruments of torture - to tear out human skin. ${ }^{3}$

To spin both wool and flax, wooden spindles were weighed down with whorls. As many as 418 spindles were excavated in eight settlement levels of the Opole stronghold, some of which with carved marks of compositions of horizontal, vertical and diagonal lines. Researchers were able to identify only single wood species (yew and spindle wood). They were in various condition, with different length - from $16 \mathrm{~cm}$ to $35 \mathrm{~cm} .{ }^{4}$ On the island on the Lake Zarańskie (Żółte, Zachodniopomorskie Voivodeship, Site 33), archaeologists found spindles which were $25-33.3 \mathrm{~cm}$ long and with diameters of $1.7 \mathrm{~cm}$ in their thickest part (Fig. 1). They were made

${ }^{2}$ Hoffmann 1964, 286; Grupa 2012, 76.

${ }^{3}$ One of the earliest comb images with a quite long single teeth row comes from the $11^{\text {th }}$ century from the Abdinghofer Altar, in the Franciscan Friary in Paderborn, Germany. The comb was used as a torture instrument to torment St Blasius; Hoffmann 1964, 286.

${ }^{4}$ A significant difference between spindle lengths could have resulted from using spindle whorls made of various materials, with a predominance of objects made of local material (limestone) -900 objects. A local character of tool manufacturing is evidenced by finds of half-products ( 97 items), siliceous and gray shales (21 items), Volhynian shale - 36 finds. A number of ceramic spindle whorls - over 94 items - is an interesting piece of information; Bukowska-Gedigowa and Gediga 1986, 33-303. 


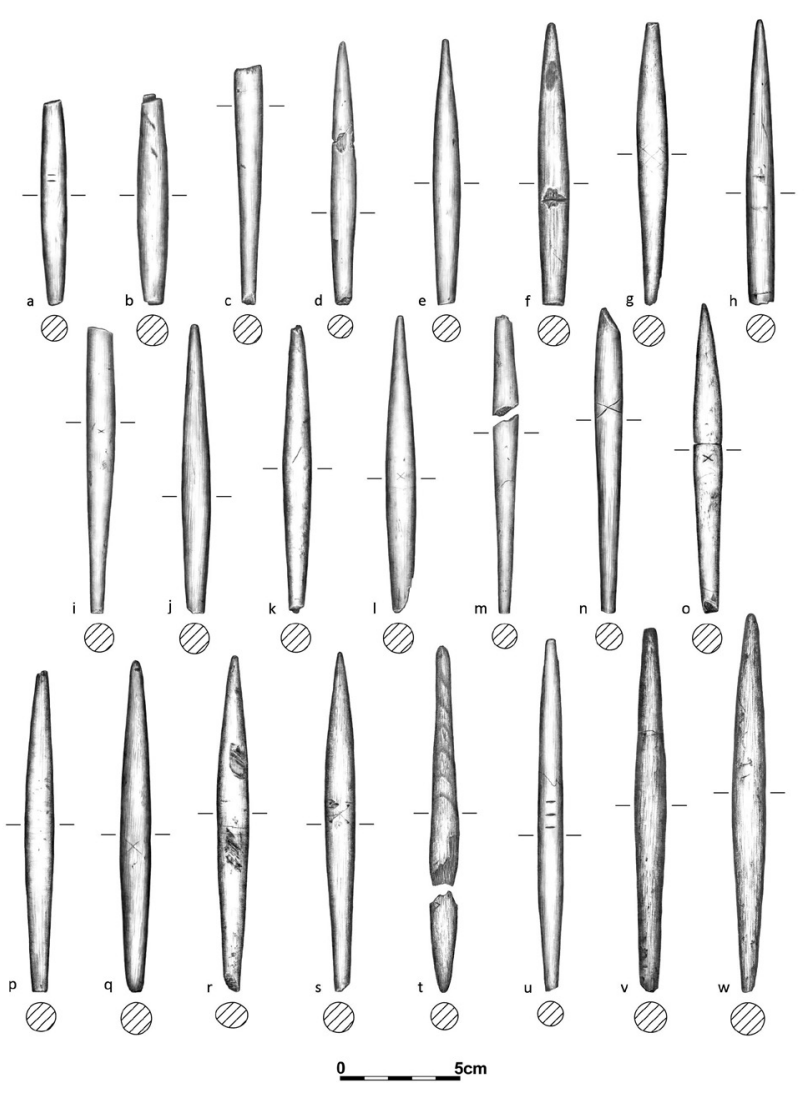

Fig. 1. Żółte, Zachodniopomorskie Voivodeship, Site 33, Spindles. Drawing B. Kowalewska.

of hazel, birch, willow wood and one example was manufactured of pine wood. ${ }^{5}$ Sixteen examples were decorated, which can be interpreted as owners' signs or the simplest way of ornamenting tools, which in fact defined the owner. The ornaments consist of two or three horizontal lines, placed at various distances from one another or X symbols of various sizes. Other single motifs were also observed, like: a diagonal checker pattern or a combination of horizontal and diagonal lines. Similar spindles, originating from the Early Middle Ages, were also found in Gdańsk, Wolin, Szczecin, and Łęczyca. ${ }^{6}$ Analogous artefacts were excavated in layers of late medieval Gdańsk in Granary Island (Wyspa Spichrzów), ${ }^{7}$ in the relics of the following granaries: Słońce, Kobziarz, Lubecki Okręt, Księżyc and Gwiazdy. These were single items in various state of preservation. As it was remarked, spindles were usually made of soft flexible wood which unfortunately was not very resistant to external conditions, and it was probably the reason why such finds are so rare, even in favourable environment for archaeological

${ }^{5}$ Grupa 2012, 77; Kowalewska 2014a, 196-203.

${ }^{6}$ Moszyński 1929, 310-312; Kamińska and Nahlik 1958, 34; Kaube 1965, 115-116; Bukowska-Gedigowa and Gediga 1986, 33289; Kowalska 2003, 299-300.

${ }^{7}$ Wyspa Spichrzów is situated in a damp area. Therefore, during every flood its ground level was under water. Every granary had its own name. In 1688 there were 303 granaries in the island.

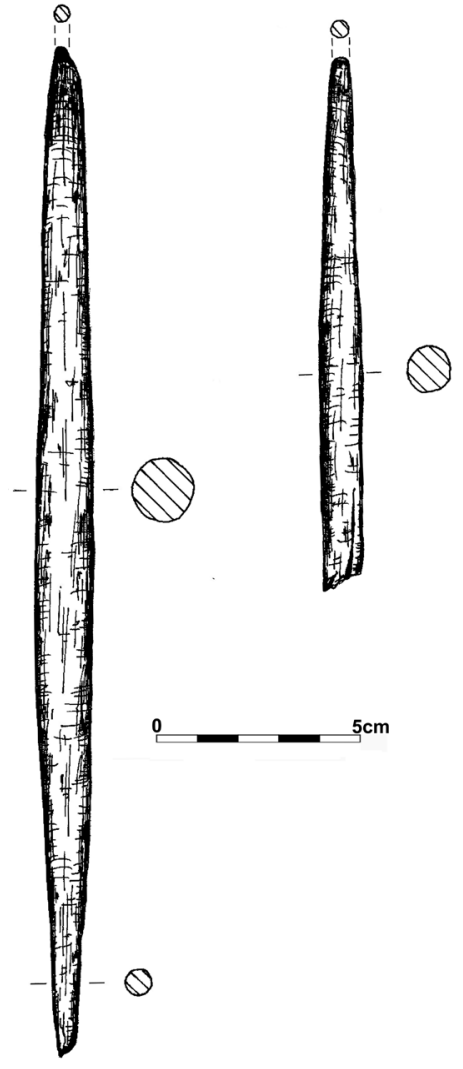

Fig. 2. Gdańsk, Panieńska St. 3a. Spindles. Drawing M. Majorek.

wood. ${ }^{8}$ The site at Panieńska St. 3a in Gdańsk, ${ }^{9}$ with almost ideal conditions for wood preservation (anaerobic environment, constant humidity) yielded only 2 spindles - the first is $24.5 \mathrm{~cm}$ long and the diameter of the thickest part is $1.5 \mathrm{~cm}$, while the other is damaged in half (Fig. 2). ${ }^{10}$ The described spindles, both from the Early and Late Middle Ages, did not differ much in size and technique of manufacturing.

Early medieval layers in Gdańsk and the site in Żółte 33 provided examples of big distaffs, with sizes from 50 to $70 \mathrm{~cm}$ (Fig. 3). This kind of tool can be classified as spadelike type. ${ }^{11}$ Distaffs from Żółte were made of hard wood - beech and oak, so they were resistant to damage while used for long. A tool of the same type was excavated in Ostrów Lednicki. ${ }^{12}$ At a site in Kołobrzeg, four wooden objects were identified as spade-like distaffs and they resembled

${ }^{8}$ Finds from Opole are exceptional, but insufficient information concerning wood types used is an obstacle in interpretation.

${ }^{9}$ The site is situated between Panieńska/Browarna/Zamkowa/ Osiek St. in the area of the last one. The Teutonic Knights settling down in Gdańsk demolished fishermen houses in the trading quarter to obtain free access to the mouth of the Motława River; Paner 2005, 31; Grupa 2012, 27.

${ }^{10}$ Grupa 2012, 77

${ }^{11}$ Kamińska and Nahlik 1958, 33-34; Kowalewska 2010, 200206; Kowalewska 2014a, 196-200.

${ }^{12}$ Grupa 2000, 141, 153, 161, Table XXIV:6, XXXII:39; Baran 2014, 182, 201, Table XXIX:2, 3, 6. 


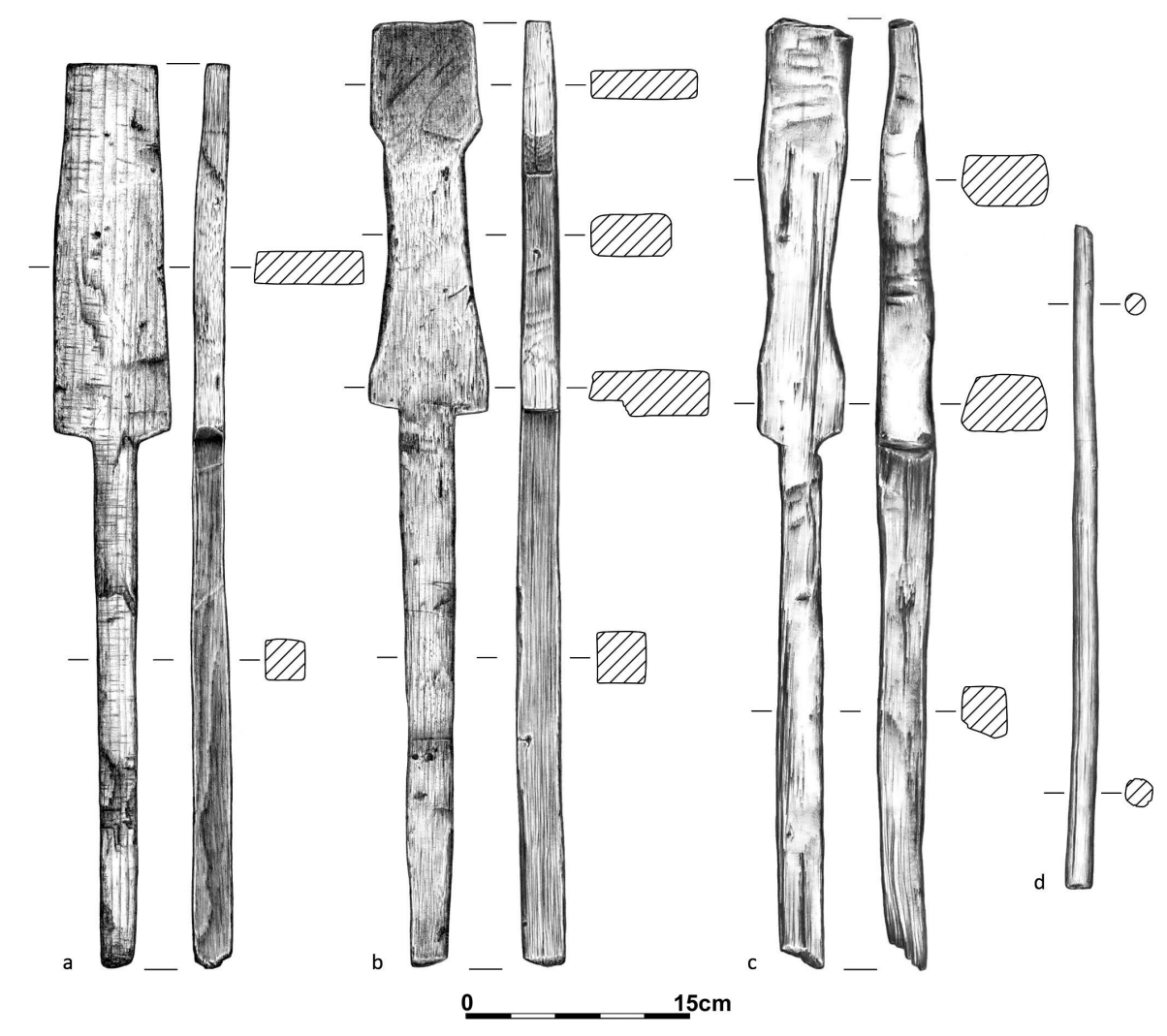

Fig. 3. Żółte, Zachodniopomorskie Voivodeship, Site 33. Distaffs. Drawing B. Kowalewska.

the aforementioned artefacts with regard to their size and shape. ${ }^{13}$ Similar historical objects were also found in Castle Hill in Szczecin during explorations of layers from the $12^{\text {th }}$ and $13^{\text {th }}$ centuries ${ }^{14}$ and in Opole, where as many as 13 items were recorded. ${ }^{15}$ The distaffs from Opole were made, among others, of oak and pine wood. ${ }^{16}$

While analysing the technique of distaffs production, we can observe that most examples from Żółte were made very carefully, which is not the case of some others (five items) from the Lednica site. ${ }^{17}$ Only two examples excavated in layers of the western bridge and one from the eastern bridge are similar to Żółte objects. They must have been made by very skilful craftsmen. The others were rather casual pieces of wood, adjusted to shapes of a required tool. Late medieval and modern times materials did not deliver any example identified as a distaff. The Opole distaffs can be characterised similarly to the Lednica examples.

However, while analysing publications about some sites in Gdańsk, we can recognise single artefacts as distaffs of

\footnotetext{
${ }^{13}$ Polak 1996, 333, Table 109:4-6.

${ }^{14}$ Cnotliwy and Rogosz 1983, 159, Fig. 135:1.

${ }^{15}$ Bukowska-Gedigowa and Gediga 1986, 198, Fig. 82:10.

${ }^{16}$ Unfortunately, not all wood types were identified.

${ }^{17}$ The quality of the distaffs from Ostrów Lednicki and Żółte was assessed by the author during conservation treatment. Objects from other sites are known to her only from illustrations; Grupa 2000, 141; Baran 2014, 182; Kowalewska 2014a, 199-200.
}

spade-like type - in Przemysł, Księżyc and Gwiazdy granaries. ${ }^{18}$ The lack of distaffs does not mean, of course, that these objects did not exist at all. Spinners had to secure them in some way, because a number of excavated spindle whorls gives evidence for intense spinning activity. If spinners could not use typical distaffs they used split fork branches (which did not cost any money) or pegs in walls, on which they hung bundles of fibres. The same situation could have been the case with a niddy-noddy where a split branch served for winding yarn, while the other end was fixed to a piece of wood or floor-pugging or sand floor. ${ }^{19}$

While studying wooden spindles and distaffs, we should pay attention to extremely rare finds of wooden spindle whorls. One artefact excavated in Wyspa Spichrzów differed from others, first of all concerning its size (the diameter was $8 \mathrm{~cm}$, see Fig. 4), and from other objects made of different materials. In comparison with, e.g. ceramic ones, the discussed find was relatively light. ${ }^{20}$ The hole for a spindle of a $1 \mathrm{~cm}$ diameter was not made centrally. In the hole there was a fragment of a wooden spindle, which perhaps belonged to the longest types, because the work would have been impossible with

\footnotetext{
${ }^{18}$ Grupa 2012, 79.

${ }^{19}$ Moszyński 1967, 327; Grupa 2000, 141.

${ }^{20}$ It is difficult to estimate a real weight of a wooden whorl, because cellulose destruction in archaeological wood often reaches
} $70-80 \%$, based on the author's own observations. 

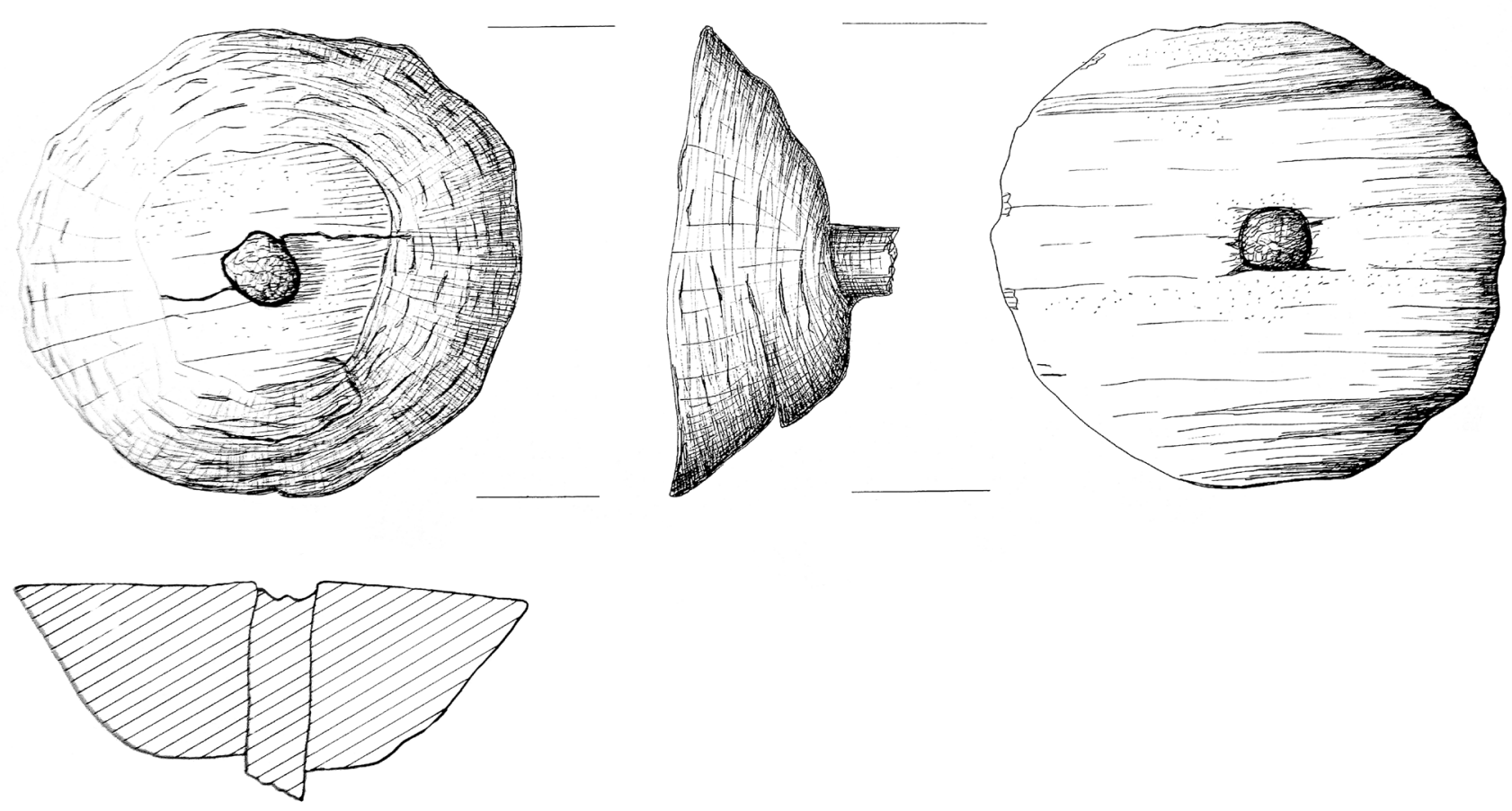

Fig. 4. Gdańsk, Wyspa Spichrzów (Granary Island). Wooden spindle whorl. Drawing M. Majorek.

a shorter tool. That object could have served for spinning yarn to produce bags and blankets ${ }^{21}$ - thick, soft and loosely spun yarn. A similar whorl was found during archaeological exploration in Wielki Młyn in Gdańsk.22 Wooden spindle whorls were used even in the $20^{\text {th }}$ century in Greece; their diameters were between 3.5 and $7 \mathrm{~cm} .^{23}$

We should remember that a distaff and a spindle were elements of every household of poor families and spinning was a common occupation of women, either in their free time or during supervising house chores. Medieval iconography presents a woman with a distaff or a spindle in various situations - while working in the kitchen stirring food in pots (Fig. 5), feeding children or poultry, in family scenes - in a carpenter or shoemaker workshop of her husband or while looking after babies. Sometimes these are satirical pictures - a drunk cobbler's wife with a distaff or a spinner beating her husband with it. ${ }^{24}$

Another tool which was necessary in textile production was a weaving sword of various sizes, made of one piece

\footnotetext{
${ }^{21}$ In Gdańsk, archaeologists excavated a high number of thick textiles with very loose yarn spun, whose density was between 4 to 7 threads per one $\mathrm{cm}$. The material analysis demonstrated that these textiles were made of woolen wastes coming from wool cleaning.

${ }^{22}$ Grupa 2012, 80, 139. Untypical spindle whorls include an object made of antler, with a diameter of $9 \mathrm{~cm}$, found together with a fragment of a wooden spindle in Ostrów Lednicki. The $3 \mathrm{~cm}$ thick flat disc 3 is provided with incisions on both surfaces of its rims; Grupa 2000, 141.

${ }^{23}$ Chmielewski 2009, 125.

${ }^{24}$ Estreicher 1933, 218-219; Schramm 1938, 8-24; Możdżyńska-Nawotka 2003, 53; Grupa 2012, 83, Fig. 15, 85, Fig. 16.
}

of wood. ${ }^{25}$ Small ones served for pushing weft on band looms - rigid heddles and tablets, while larger tools were used with treadle looms. Their shafts had lenticular, trapezoid or triangular cross-sections, which helped in beating the thread in a pass made by warp threads. Small swords, used probably for ribbons/bands production were found in Opole, Wrocław, Żółte (Fig. 6) and Lake Lednica. ${ }^{26}$ A huge weaving sword with the preserved length of $96.6 \mathrm{~cm}^{27}$ is presumably the only archaeological find of such a large size. It is not known, of course, what the maximum length of the sword was, which would allow to define the average vertical loom's width used in Żółte. There are also other objects preserved in fragments, indicating their usage with vertical looms, ${ }^{28}$ because a $40 \mathrm{~cm}$ long sword long could not have been used for producing bands. ${ }^{29}$

\footnotetext{
${ }^{25}$ The author knows examples of weaving swords made of coniferous wood, but their small number does not give any grounds to assume that such artefacts were made of only that kind of wood. The site in Opole yielded a sword made of oak wood, but it is a single case.

${ }^{26}$ Hołubowicz 1956, 205; Ostrowska 1962, 316; Kaźmierczyk 1970, 513; Bukowska-Gedigowa and Gediga 1986, 46-47, Fig. 16:6, 101, 102-103, Fig. 37:11, 21; Grupa 2000, 141; Kowalewska 2014b, 213.

${ }^{27}$ Kowalewska 2014b, 213-214. This sword's length was successfully reconstructed during conservation treatments on the basis of the width and cross-section of working sword's part.

${ }^{28}$ Kowalewska 2014b, 213, Fig. 6.91:a, b.

${ }^{29} \mathrm{We}$ must be very cautious while interpreting identifications of weaving swords, as many researchers consider them, e.g. children toys. Textile specialists describe them as tools used in weaving; Broholm and Hald 1940, 144.
} 


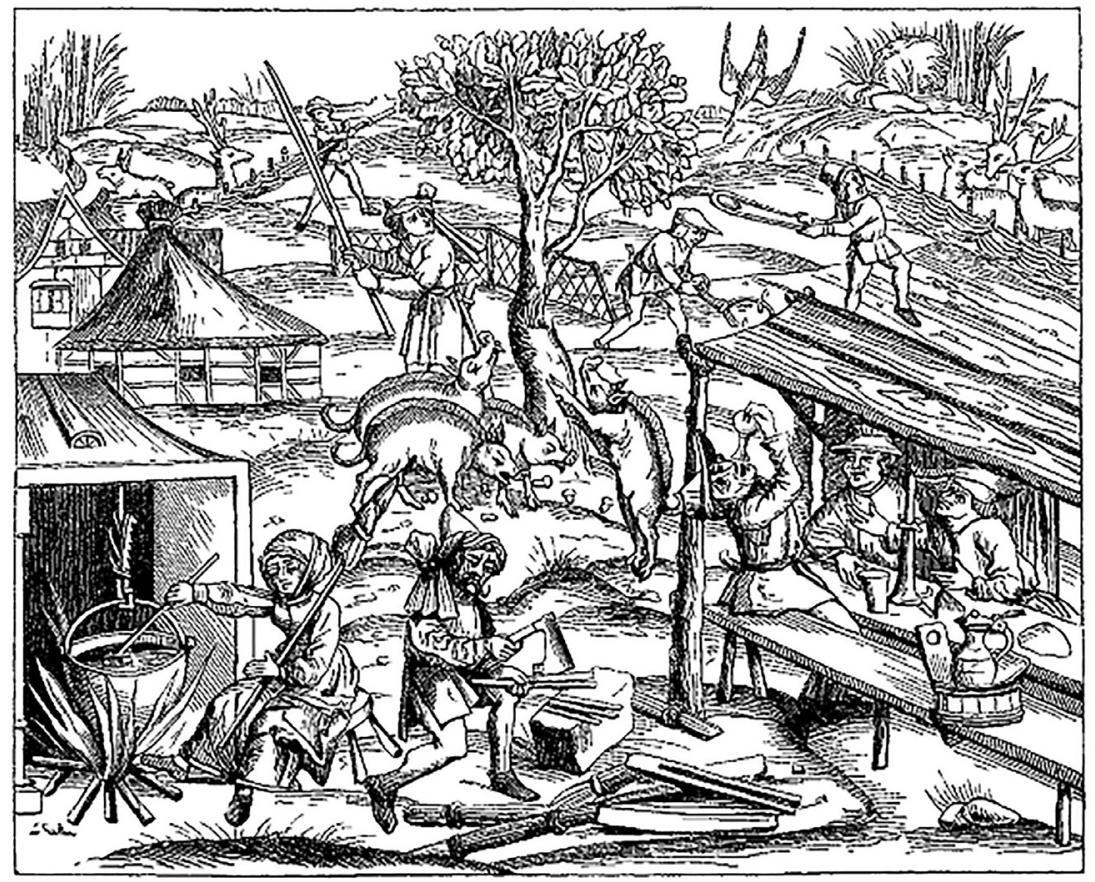

Fig. 5. Life in the country: a woman with a distaff stirring food in a pot, woodcut published in Virgil edition, Lyon 1517. After Grupa 2012, 78.

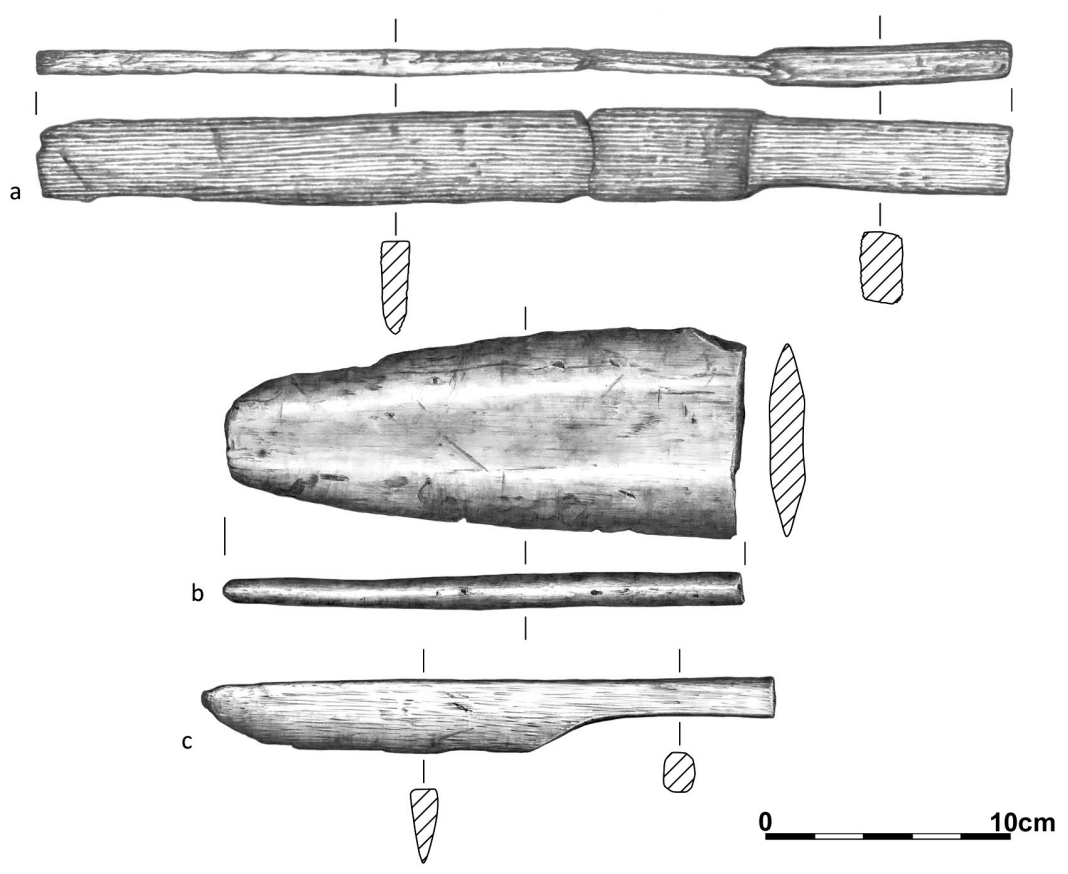

Fig. 6. Żółte, Zachodniopomorskie Voivodeship, Site 33. Weaving swords. Drawing B. Kowalewska.

Similar observations were made in the case of the Lednica materials, where small swords were over $23 \mathrm{~cm}$ long, and larger ones were much longer. On the other hand, their state of preservation does not allow detailed interpretations. ${ }^{30}$ It must also be remarked that swords deposited in water for nearly a thousand years have smooth surfaces. Later swords used for band production were of similar sizes as early medieval ones. The sword from Panieńska St. 3a in Gdańsk, dated to $1483-1515$, had a length of $26 \mathrm{~cm}$ and the shaft width was $2.4 \mathrm{~cm}$ (Fig. 7). ${ }^{31}$ Its handle was $5.6 \mathrm{~cm}$ long and

\footnotetext{
${ }^{30}$ Grupa 2000, 141, Tabl. XXVII:13; XXXI:10, 11.
}

${ }^{31}$ Grupa 2012, 152. 


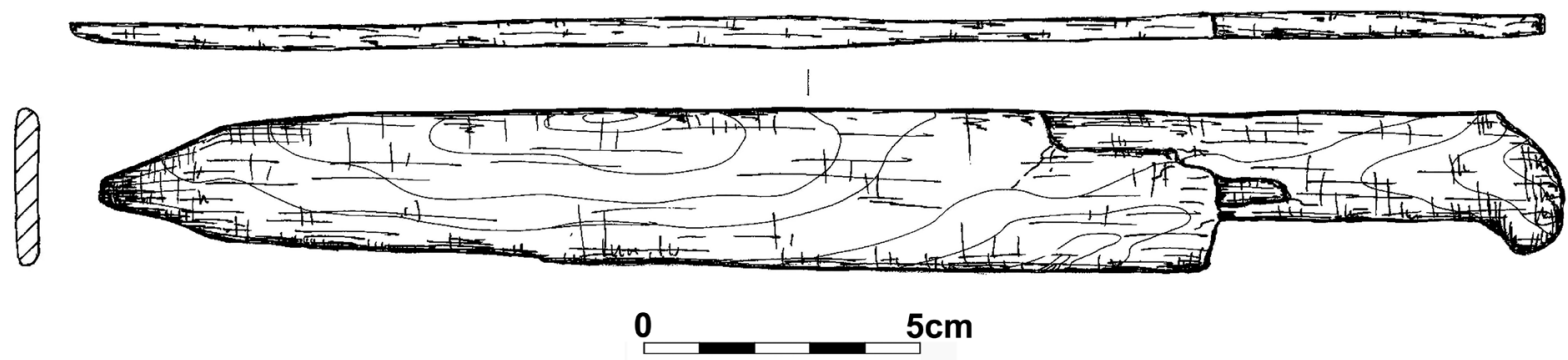

Fig. 7. Gdańsk, Panieńska St. 3a. Spindle, weaving sword. Drawing M. Majorek.
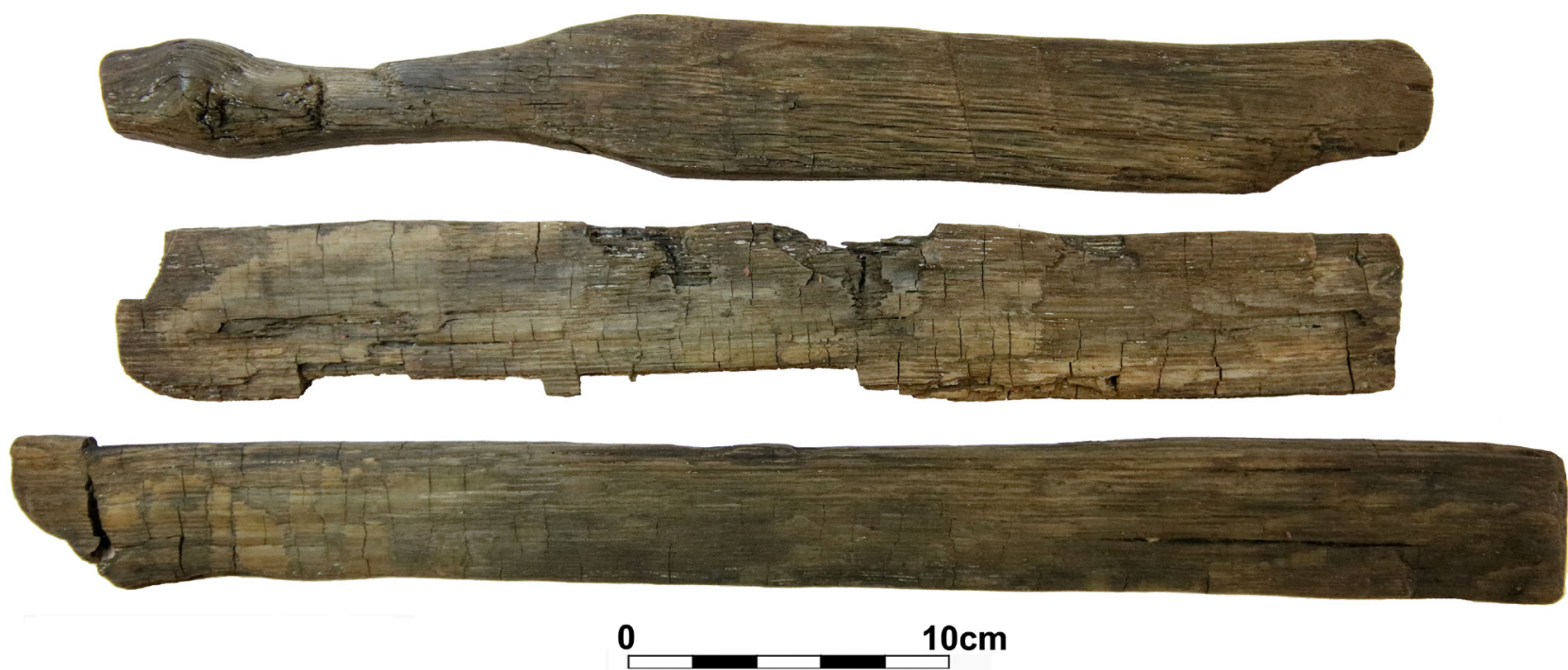

Fig. 8. Gdańsk, Wyspa Spichrzów-Jezus. Weaving sword. Photo J. Michalik.

$1.9 \mathrm{~cm}$ wide, while its blade was $2.4 \mathrm{~cm}$ wide and was slightly thicker in its central part. The object's total thickness was from $0.4 \mathrm{~cm}$ to $0.5 \mathrm{~cm}$. Another sword excavated in Gdańsk is an object from a granary named 'Jesus' and was found in $2016 .{ }^{32}$ Its total length was $38 \mathrm{~cm}, 16$ of which was a $2.5 \mathrm{~cm}$ wide handle. The blade length was $22 \mathrm{~cm}$ and it was $4.5 \mathrm{~cm}$ wide and $1 \mathrm{~cm}$ thick (Fig. 8). The sword was made of oak wood, like one of the swords from Opole. ${ }^{33}$ The others with identified taxons were made of conifer wood, mainly pine. In the course of four centuries these tools did not change their shapes, they varied only in size.

A similar situation was reported in the case of a multifunctional tool used for making fishermen nets and bands, that is, a netting needle. An example was excavated in Żółte ${ }^{34}$ and, since it was classified as a typical fishermen tool, similar artefacts were treated likewise in papers discussing Gdańsk

\footnotetext{
${ }^{32}$ Research made by Renata Wiloch-Kozłowska in 2016.

${ }^{33}$ Bukowska-Gedigowa and Gediga 1986, 333-339.

${ }^{34}$ Kaźmierczak 2014, 239.
}

fishing. ${ }^{35}$ Netting needles are known not only in Polish territories, but can be found in all Slavic areas, ${ }^{36}$ although not all of them appeared with nets and fishing equipment (Kołobrzeg, Kamień Pomorski). In Gdańsk, they were more often registered in early medieval layers, ${ }^{37}$ while at Panieńska St. 3a only one item was excavated. It was related to fishing and fishers in $14^{\text {th }}$ century layers ${ }^{38}$ (Fig. 9). ${ }^{39}$ The needle was prepared very precisely, but as Rulewicz remarked, they all were usually made very carefully. ${ }^{40}$ A netting needle could be used for not only net and net-sacks production, but

${ }^{35}$ Rulewicz 1994, 90-95.

${ }^{36}$ Moszyński 1967, 328-329; Rulewicz 1994, 95.

${ }^{37}$ One of them was made of spindle tree part; Rulewicz 1994 , 90. It is very difficult to obtain cross-sections of this type of archaeological objects; we can only generally claim that they were made of some broad-leaved trees, very carefully selected for these tools - hard, but flexible.

${ }^{38}$ Grupa 2012, 152.

${ }^{39}$ Panieńska St. 3 delivered 139 bobs; Dąbrowski 2009, 53.

${ }^{40}$ Rulewicz 1994, 90. 


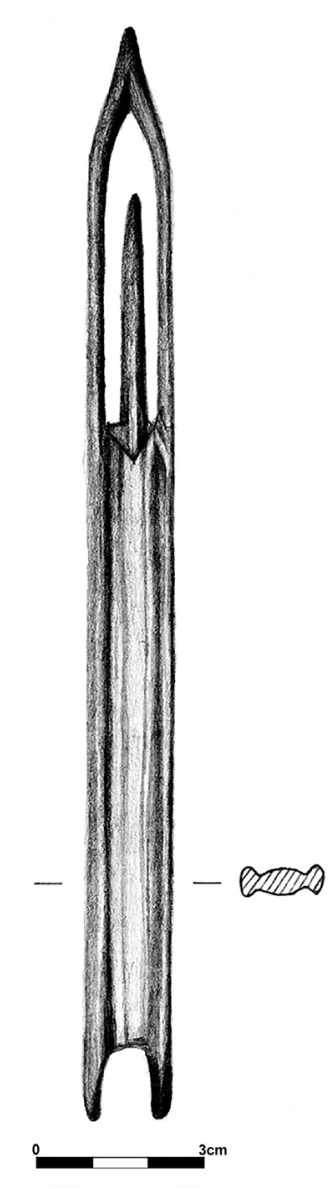

Fig. 9. Gdańsk, Panieńska St. 3a. Netting needle. Drawing J. Słońska.

also as a shuttle for making bands and garters. ${ }^{41}$ A shuttle was another tool used for weaving and remains of such artefacts were also excavated in Opole, Żółte and Ostrów Lednicki. $^{42}$

The number of wooden elements delivered by excavations generates difficulties in proper interpretation of particular details belonging to vertical and horizontal looms. Explorations in Opole in the 1930s yielded fragments of a horizontal loom: two weaving shuttles, two pulleys lying alongside which served for heddle hanging and relics of vertically placed poles. According to site explorers, the latter were defined as remains of the loom side frame. They were dated to the $2^{\text {nd }}$ half of the $12^{\text {th }}$ century and the beginning of the $13^{\text {th }}$ century. ${ }^{43}$ They match the chronology of parts of horizontal looms from Gdańsk: loom side frames in a better condition than the Opole finds (their preserved length was $147 \mathrm{~cm}$ ) and a blockage of warp frontal beam. ${ }^{44}$ Horizontal loom elements excavated during later explorations in Gdańsk

${ }^{41}$ Grupa 2012, 158.

${ }^{42}$ Maik 1991, 6; Rulewicz 1994, 90; Grupa 2000, 141; Grupa 2012, 152; Kowalewska 2014b, 214.

${ }^{43}$ Sage 1936, 330; Maik 1991, 5-6; Maik 1997, 49.

${ }^{44}$ Kamińska and Nahlik 1958, 44-48, 89.
(1960-2002) did not deliver any new piece of information concerning looms used in medieval and post-medieval towns, because they mainly consisted of wooden pulleys for heddle hanging. All statements from the 1950s and completing remarks made by Jerzy Maik are still valid. ${ }^{45}$ A wooden pulley found at Panieńska St. 3a, made of coniferous wood (pine?), is rather large in comparison with analogical objects from other sites (Fig. 10) ${ }^{46}$ (its diameter is $8.5 \mathrm{~cm}$, its thickness is $1.5 \mathrm{~cm}$, and the central opening diameter is $1.0 \mathrm{~cm}$ ). The object was made very carefully and precisely. A groove hollowed out on the perimeter, triangular in the profile, has an identical depth in the preserved length $-0.9-1.1 \mathrm{~cm}$. The ring corresponds with its measures to heddles pulley in a horizontal loom. ${ }^{47}$

Weaving tools (spindles, spindle whorls, distaffs, weaving swords, netting needles) discussed in this paper were in most cases excavated within household and settlement areas, although in Ostrów Lednicki they were situated in layers of early medieval bridges, at the depth of about $6 \mathrm{~m}$ (eastern bridge, so-called Gniezno bridge) ${ }^{48}$ and c. $9 \mathrm{~m}$ (western bridge, so-called Poznań bridge). ${ }^{49}$ It is difficult to identify circumstances in which the objects were sunk in water (it also concerns all other artefacts excavated there). The easiest explanation is their accidental sinking, as spinning on a busy narrow bridge (its width was 4.1-4.2 m) was rather impossible. ${ }^{50}$ We cannot define, either, whether the tools were placed in water in the same period. During underwater exploration, a few phases of use of both bridges in the Early Middle Ages were isolated. Due to this fact, every tool could have gone into water in different time. Wooden tools used in textile production which were discussed above form to a rather small assemblage, when compared with ceramic and stone finds of spindle whorls. However, they play a crucial role in building weaving history and defining technological changes in textile industry, not only in Poland, but also in Europe.

${ }^{45}$ Kamińska and Nahlik 1958, 89-97; Maik 1997, 48-61; Grupa 2012,96 .

${ }^{46} \mathrm{~A}$ ring from Wrocław had a diameter of $4.3 \mathrm{~cm}$; Ostrowska 1962, 316. A pulley excavated under the Market Hall in Gdańsk had a diameter of $6.5 \mathrm{~cm}$, the hole - $2 \mathrm{~cm}$; Kasprzak 2009, 10; another pulley from early medieval layers in Gdańsk had a diameter of $5.8 \mathrm{~cm}$, a thickness of $1.5 \mathrm{~cm}$ and the central hole diameter was $1.8 \mathrm{~cm}$; Kamińska and Nahlik 1958, 48, Fig. 14. Late medieval layers from Olejarna St. 96 (Site 255/002/08) delivered a pulley (inv. No. 4337) with a diameter of about $7.0 \mathrm{~cm}$. It was $1.3 \mathrm{~cm}$ thick, the central hole diameter was $1.2 \mathrm{~cm}$, and the hollowed groove is $0.5 \mathrm{~cm}$ deep (the ring is smaller as a result of longitudinal and transverse wood shrinkage after excavating from the soil). The pulley is similar to the object from Panieńska St. 3a.

${ }^{47}$ Grupa 2012, 96.

${ }^{48}$ Kola 2000, 12.

${ }^{49}$ Kola 2014, 23. During underwater explorations divers are not able to distinguish small elements in wood mass. Distaffs are big and massive tools and they can be identified in the course of the work. We cannot exclude that small objects were sunk in water, but they were not recognised.

${ }^{50}$ Wilke 2000, 58 . 


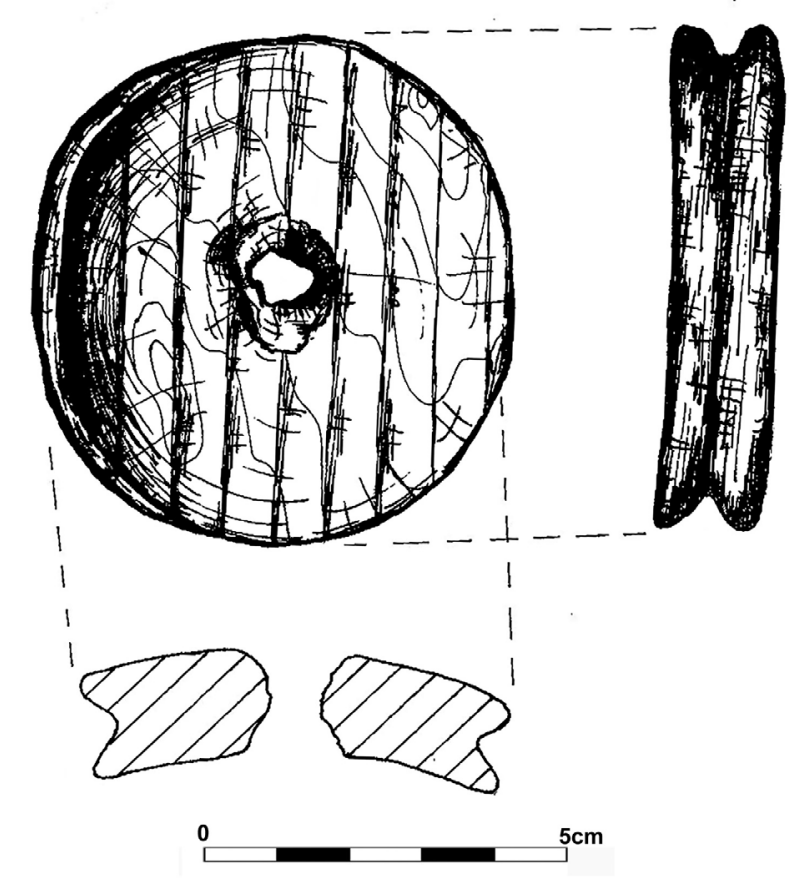

Fig. 10. Gdańsk, Panieńska St. 3a. Wooden pulley. Drawing M. Majorek.

\section{Bibliography}

Baran D. 2014. Wyposażenie gospodarstwa domowego, przedmioty osobiste, atrybuty handlu. In: A. Kola, G. Wilke (eds.), Wczesnośredniowieczne mosty przy Ostrowie Lednickim. Mosty Traktu Poznańskiego 2. Kraków, 177-201.

Broholm H. C., Hald M. 1940. Costumes of the Bronze Age in Denmark: Contributions to the Archaeology and Textile-History of the Bronze Age. Copenhagen.

Bukowska-Gedigowa J., Gediga B. 1986. Wczesnośredniowieczny gród w Opolu. Wrocław, Warszawa, Kraków.

Chmielewski T. J. 2009. Po nitce do kłębka... O przędzalnictwie i tkactwie młodszej epoki kamienia w Europie Środkowej. Warszawa.

Cnotliwy E., Rogosz R. 1983. Wykop V. In: E. Cnotliwy, L. Leciejewicz, W. Łosiński (eds.), Szczecin we wczesnym średniowieczu. Wzgórze Zamkowe. Wrocław, Warszawa, Kraków.

Dąbrowski Ł. 2009. Drewniane przedmioty związane ze średniowiecznym rybołówstwem z wykopalisk archeologicznych z Gdańska. Typescript, Toruń.

Estreicher K. 1933. Minjatury Kodeksu Bema oraz ich treść obyczajowa. "Rocznik Krakowski” 24, 199-217.

Grupa M. 2000. Sprzęty i wyposażenie gospodarstwa domowego. In: Z. Kurnatowska (ed.), Mosty Traktu Gnieźnieńskiego 1. Lednica, Toruń, 139-162.

Grupa M. 2012. Wetniane tekstylia pospólstwa i plebsu gdańskiego (XIV-XVII w.) i ich konserwacja. Toruń.

Hoffmann M. 1964. The Warp-Weighted Loom. Studies in the History and Technology of an Ancient Implement. Studia Norvegica 14. Oslo.

Hołubowicz W. 1956. Opole w wiekach X-XI. Katowice.

Kamińska J., Nahlik A. 1958. Włókiennictwo gdańskie X-XIII w. Łódź.

Kasprzak M. 2009. Zabytki drewniane ze stanowiska 5 w Gdańsku - Hala Targowa. In: H. Paner (ed.), Archeologia Gdańska 4, Gdańsk, 7-17.

Kaube A. 1965. Włókiennictwo wczesnośredniowiecznego Wolina (stanowisko wykopaliskowe nr 4). "Materiały Zachodniopomorskie" 13, 91-143.

Kaźmierczak R. 2014. Tools for the Production of Fishing Equipment. In: W. Chudziak, R. Kaźmierczak (eds.), The Island in Żótte on Lake Zarańskie. Early Medieval Gateway into West Pomerania. Toruń, 239.

Kaźmierczyk J. 1970. Wrocław lewobrzeżny we wczesnym średniowieczu. Wrocław, Warszawa, Kraków.

Kola A. 2000. Archeologiczne badania podwodne na reliktach mostu. In: Z. Kurnatowska(ed.), Mosty Traktu Gnieźnieńskiego 1. Lednica, Toruń, 11-27.

Kola A. 2014. Archeologiczne badania podwodne na reliktach mostów (do 2003 roku). In: A. Kola, G. Wilke (eds.), Wczesnośredniowieczne mosty przy Ostrowie Lednickim. Mosty Traktu Poznańskiego 2. Kraków, 13-32. 
Kowalewska B. 2010. Przędzalnictwo i tkactwo na wyspie Jeziora Zarańskiego (Żólte, stan. 33, gm. Drawsko Pomorskie. In: P. Kucypera, S. Wadyl (eds.), Życie codzienne przez pryzmat rzeczy. Toruń, 197-214.

Kowalewska B. 2014a. Items Associated with Spinning and Weaving. In: W. Chudziak, R. Kaźmierczak (eds.), The Island in Żótte on Lake Zarańskie. Early Medieval Gateway into West Pomerania. Toruń, 196-211.

Kowalewska B. 2014b. Tools and Weaving Products. In: W. Chudziak, R. Kaźmierczak (eds.), The Island in Żótte on Lake Zarańskie. Early Medieval Gateway into West Pomerania. Toruń, 212-217.

Kowalska A. 2003. Pozostałe przedmioty drewniane. In: W. Łosiński (ed.), Szczecin we wczesnym średniowieczu. Wschodnia część suburbium. Szczecin, 298-300.

Maik J. 1991. Tekstylia wczesnośredniowieczne z wykopalisk w Opolu. Warszawa, Łódź.

Maik J. 1997. Sukiennictwo elbląskie w średniowieczu. Acta Archaeologica Lodziensia 41. Łódź.

Moszyński K. 1929. Kultura ludowa Słowian, cz. 1, Kultura Materialna. Kraków.

Moszyński K. 1967. Kultura ludowa Stowian, cz. 1, Kultura Materialna. Kraków.

Możdżyńska-Nawotka M. 2003. O modach i strojach. Wrocław.

Ostrowska E. 1962. Drewniane budownictwo i obróbka drewna we wczesnośredniowiecznym Wrocławiu. "Etnografia Polska" 6, 302-320.

Paner H. 2005. Wyspa Skarbów. "Archeologia Żywa” 32 (2), 25-32.

Polak Z. 1996. Przedmioty wykonane z drewna. In: M. Rębkowski (ed.), Archeologia średniowiecznego Kołobrzegu. Badania przy ul. Ratuszowej 9-13. Kołobrzeg, 331-336.

Rulewicz M. 1994. Rybołówstwo Gdańska na tle ośrodków miejskich Pomorza od IX do XIII wieku. Prace Komisji Archeologicznej 11. Gdańsk wczesnośredniowieczny 10. Wrocław.

Sage G. 1936. Die Gewebereste aus dem alten Oppeln. “Altschlesien” 6, 322-332.

Schramm A. 1938. Der Bilderschmuck der Frühdrucke 21, W. Schmidt (ed.), Leipzig.

Wilke G. 2000. Analiza chronologiczno-przestrzenna struktur palowych i próba rekonstrukcji. In: Z. Kurnatowska (ed.), Mosty Traktu Gnieźnieńskiego 1. Lednica, Toruń, 57-71.

\section{Streszczenie}

\section{Narzędzia drewniane w wytwórczości tkackiej pochodzące z średniowiecznej Polski}

Drewniane narzędzia wykorzystywane w tkactwie należą wśród znalezisk archeologicznych do rzadkości. Przyczyny tego zjawiska są różnorodne. Jedną z nich jest środowisko niesprzyjające przetrwaniu zabytków wykonanych z surowców organicznych. Drugą, niewłaściwa identyfikacja zabytków, ich błędna interpretacja już na etapie badań archeologicznych. Kolejną, niestety dosyć częstą, to brak opracowań czy skromna liczba publikacji dotyczących tej kategorii zabytków.

Omawiana kolekcja narzędzi pochodzi z badań na grodzisku w Opolu, z Gdańska oraz z wyspy w Żółtym, st. 33 na Jeziorze Zarańskim na Pomorzu Zachodnim. Ta ostatnia, jak dotąd, stanowi największy zbiór narzędzi tkackich w Polsce. Badania gdańskich nawarstwień dostarczyły niewielu tego typu zabytków, ale są świetnym uzupełnieniem wiedzy związanej z tą wytwórczością w średniowieczu i czasach nowożytnych. Należy zauważyć, że to właśnie zabytki z Żółtego, poza Gdańskiem i Opolem, są najlepszym przykładem użytkowania drewnianych narzędzi tkackich przez małe społeczności. Wynika z tego, że były to grupy samowystarczalne w zakresie tkactwa - począwszy od wstępnej obróbki, a kończąc na wytwarzaniu tkanin wełnianych i lnianych na krośnie pionowym i poziomym. 
